\title{
Erratum to: Forest-water dynamics within a mountainous catchment in Austria
}

\author{
Elisabeth Pötzelsberger ${ }^{1} \cdot$ Hubert Hasenauer $^{1}$
}

Received: 31 March 2015/Accepted: 31 March 2015/Published online: 8 April 2015

(C) Springer Science+Business Media Dordrecht 2015

\section{Erratum to: Nat Hazards \\ DOI 10.1007/s11069-015-1609-x}

In Table 3 (Appendix), units and values of $\mathrm{VPD}_{\text {open }}$ and $\Psi_{\text {open }}$, and $\mathrm{VPD}_{\text {close }}$ and $\Psi_{\text {close }}$ were confused.

The online version of the original article can be found under doi:10.1007/s11069-015-1609-x.

Elisabeth Pötzelsberger

elisabeth.poetzelsberger@boku.ac.at

1 Institute of Silviculture, University of Natural Resources and Life Sciences, Vienna, Peter-JordanStr. 82, 1190 Vienna, Austria 